\title{
SOME REMARKS ON THE ANATOMY OF THE MELANOTAENIINAE
}

\author{
BY
}

\author{
Dr. L. F. DE BEAUFORT
}

\begin{abstract}
The freshwater of Australia, New Guinea and some of the neighbouring islands are inhabited by peculiar fishes belonging to the Atherinidae and which are chiefiy distinguished by their compressed elevated form, long second dorsal and anal fins and generally by the presence of strong pungent spines in dorsals, anal and ventrals. The upperjaw is bent and provided with well developed teeth, which more or less extend to its outside. They are generally considered to form a distinct subfamily, the Melanotaeniinae.
\end{abstract}

MAX WEBER (3) was the first to point out their importance from a geographical point of view. He considered them as freshwater-fishes, rarely found in brackish water, for which the sea forms an unpassable barrier. At the time WeBER wrote his paper, the Melanotaeniinae were only known from Australia and New Guinea, two landmasses which certainly have been connected together in recent geological times. His prophecy, that they might occur in the islands near New Guinea, which also have been connected with the larger island, has been prooved to be true later (WEBER 4, DE BEAUfORT 1) and has greatly strengthened his opinion on the distribution of these fishes.

TATE REgan (6) to the contrary, who has given a valuable revision of the Melanotaeniinae, does not think that their distribution has been much influenced by the sea. About their affinity he says: "In their osteology these fishes do not differ in any way from the other Atherinidae". "I do not think them worthy to rank as a subfamily, much less as a family".

As I had the opportunity to study the anatomy of several of the New Guinea-species of Melanotaeniinae in the Zoological Museum of Amsterdam, I could think of no subject more fit for this volume, than to give the results here.

The following species have been examined: Rhombatractus kochi M. Web., Chilatherina sentaniensis (M. Web.), Melanotaenia dumasi M. Web., Melanotaenia maculata M. Web., and Glossolepis incisus M. Web. For comparision I examined as well the european Atherina presbyter L. as Craterocephalus nouhuysi (M. Web.) and Pseudomugil novae-guineae M. Web. from the freshwater of New Guinea and Telmatherina celebensis Blgr. from the interior of Celebes. The two lastnamed species have sometimes been united with the Melanotaeniinae (cf. JORDAN \& HuBbS 2).

My osteological study was greatly facilitated by means of a number of Röntgen-fotos, which my friend Dr. N. VooRHOEve kindly made for me.

1. Osteology. The skull does not show any particularities. The supra-occipital is well developed, separating the small parietals, which can hardly be detected, as the fissures between them and the large frontals are almost obsolete. The occipitalia lateralia are large and meet above the basioccipital. The epioticum has a posterior process of moderate extent, which is scarcely ragged. The crest of the supra-occipital too is feeble and directed posteriorly. A basisphenoid is present in the form of a small rodlike bone in the middle of the entrance of the myodome. The alisphenoids are small, the brain-cavity being largely closed in front by connective tissue only, vomer and parasphenoid 
show the usual arrangement. The opisthoticum is present and well developed. The quadratum is small and the symplecticum reduced to a long slender bone,

Entopterygoid and Metapterygoid are well developed, although thin.

The maxillaries show the form, characteristic of the Atherinidae, being broader in their proximal part than in their distal part, but the praemaxillaries are of a totally different form. In typical Atherinidae the upperjaw is protractile and the praemaxilla has the usual proximal peduncle, which allows the sliding of the jaws forwards and backwards along the foremost part of the cranium. This peduncle

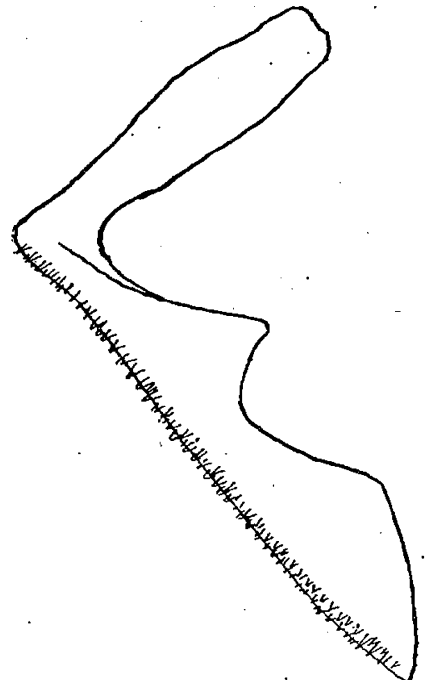

Fig. 1. Praemaxilla of Atherina presbyter L. Enlarged. is well developed in Atherina, also in Telmatherina and Pseudomugil and still more in Craterocephalus, which has a very protractile mouth (Figs. 1, 2, 3). In the speeies mentioned the frontedge, which bears the small teeth, is straight or almost so.

In the Melanotaeniinae however the sliding peduncle is absent. The proximal part is broad and flattened in a horizontal plane, and the frontedge shows a more or less abrupt bent (Fig. 4).

The vertebrae are fewer in number than in most Atherinidae. I find the following numbers:

Rhombatractus kochi 36, Melanotaenia dumasi 32, Chilatherina sentaniensis 37, Glossolepis incisus 36. In Atherina presbyter I find 51 vertebrae, Atherinopsis californiensis has, according to STARKS (5) 50-57 vertebrae, but I do not think these difference of importance, as Telmatherina celebensis has 33 vertebrae, Craterocephalus nouhuysi 37 and Pseudomugil novae-guinea 33.

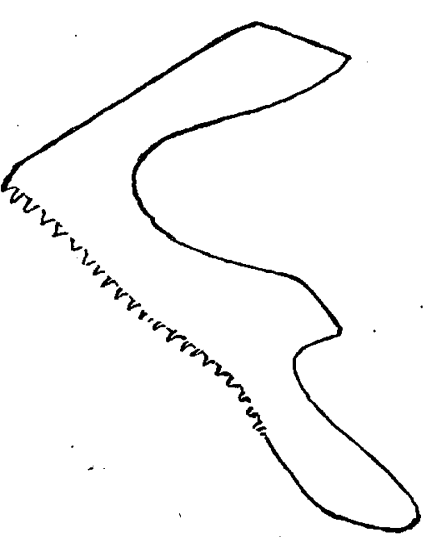

Fig. 2. Praemaxilla of Telmatherina celebensis Blgr. Enlarged.

In all the species examined the first two vertebrae do not carry ribs, although they have strong parapophyses. In the following vertebrae the ribs are attached to the hinderborder of the parapophyses, which are rather long and slender. The ribs strengthen the walls of the airbladder in the postanal part of the body-cavity, but they are not expanded as is the case in some species of Atherina. The last pair of ribs are smaller than the others, inserted low

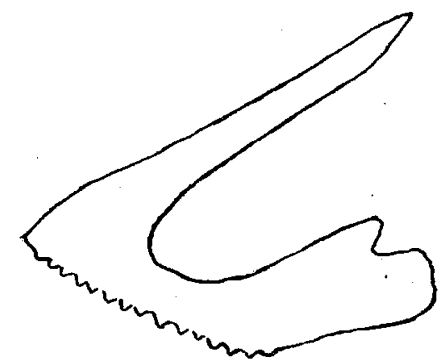

Fig. 3. Praemaxilla of Craterocephalus nouhuysi (M. Web.). Enlarged. down on the parapophyses and connected with the posterior wall of the airbladder. The prae-dorsal neurapophyses are compressed into thin bony plates, an arrangement which is typically atherinoid. The neurapophyses of the last four vertebrae help the hypural in suspending the caudal fin. The pterygophores are feeble, excepting these which carry the dorsal and anal spines.

The number of pairs of ribs is a little different in the specimens examined, viz. in Rhombatractus kochi and Melanotaenia dumasi 19 ,

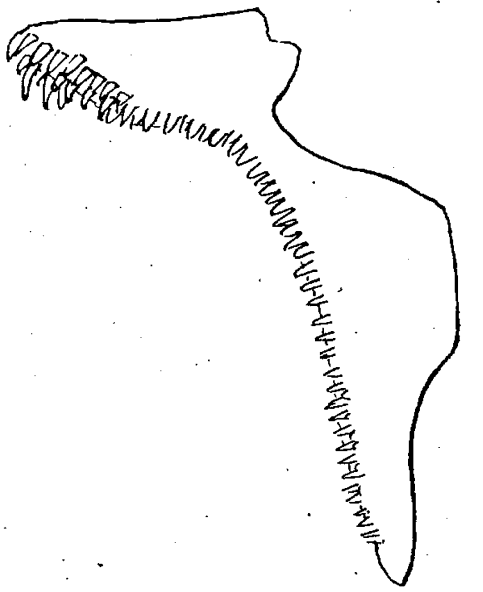

Fig. 4. Praemaxilla of Rhombatractus kochi M. Web. Enlarged.

in Glossolepis incisus 20, in Chilatherina sentaniensis 21. As I only examined one specimen of each, these differences may be individual. Telmatherina celebensis has 16, Craterocephalus nouhuysi 17, Atherina presbyter 25 and Pseudomugil novae-guineae 12 pairs of ribs.

The shoulder-girdle is typically atherinoid. The limbs of the post-temporal are slender, the upper one attached to the epioticum and the lower one by ligament to the opisthoticum. The supracleithrum is small and scarcely projects above the cleithrum. The scapula is inserted rather high up on the cleithrum and has a foramen almost in the middle of the bone. The coracoid is long and rather broad, ventrally attached to a vertical wing of the cleithrum between its inner and outer raised edge.

The branchial arches do not show any particularities, from which they might differ from other 
Atherinidae. The pharyngo-branchial of the first arch is normally developed and bears no teeth, that of the second one has an elongate patch of teeth and those of the third and fourth are united into one large oval patch. All the teeth are conical and rather widely set. The triangular lower pharyngeals are separated. The arches bear knob-like gillrakers on both sides, excepting the outer row of the first arch, which are long and numerous in Glossolepis, less so in Rhombatractus and Chilatherina and still less in Melanotaenia.

There are four radials, the upper one is small and in front of it some pectoral rays are directly attached to the scapula. Two radials articulate with the scapula and two with the coracoid.

The pelvics, which are placed in a horizontal plane in Atherina, Telmatherina, Craterocephalus and in general in all forms with a rounded belly, have rotated in a vertical direction, so that they form a sharp edge on cross-section.

2. Digestive organs. The intestinal tract is rather different in the species examined, so that they are better treated separately. In Atherina presbyter the gut forms a tube, which has about the same width in its whole course. It runs hindwards, then forwards along the ventral wall of the abdomen and then again hindwards along the dorsal side, from where it bends down to the anus. In Rhombatractus the gut forms one loop too, but immediately behind the pharynx it is widened into a thick-walled stomac and the dorsal portion is very short, as it curves downard to the anus immediately after turning upwards after the ventral course. This same arrangement is found in Craterocephalus and in Telmatherina celebensis. In Chilatherina sentaniensis the walls of the intestine are much thinner and the stomac is less well defined. The ventral portion is very short and the dorsal one very long. This part of the gut runs hindwards far behind the anus into the postanal part of the abdomen. It is reflected here and runs again forwards and then downwards to the anus.

In Melanotaenia dumasi the gut is still longer. Its walls are thin and there is no pronounced stomac. The gut first runs hindwards to far into the postanal part of the body-cavity, then curves downwards and forwards to almost below the pha-. rynx. From here it runs in an upward direction and forms two coils, one situated in the other (see Fig. 5), before attaining the anus. In the specimen examined which was photographed with Röntgenrays previously, the whole intestine was filled with a blackish mud, which must be of mineral consistence, as it is apparently unpenetrable for Röntgen-rays.

In Melanotaenia maculata $M$. Web. I find the same arrangement excepting that the inner of the

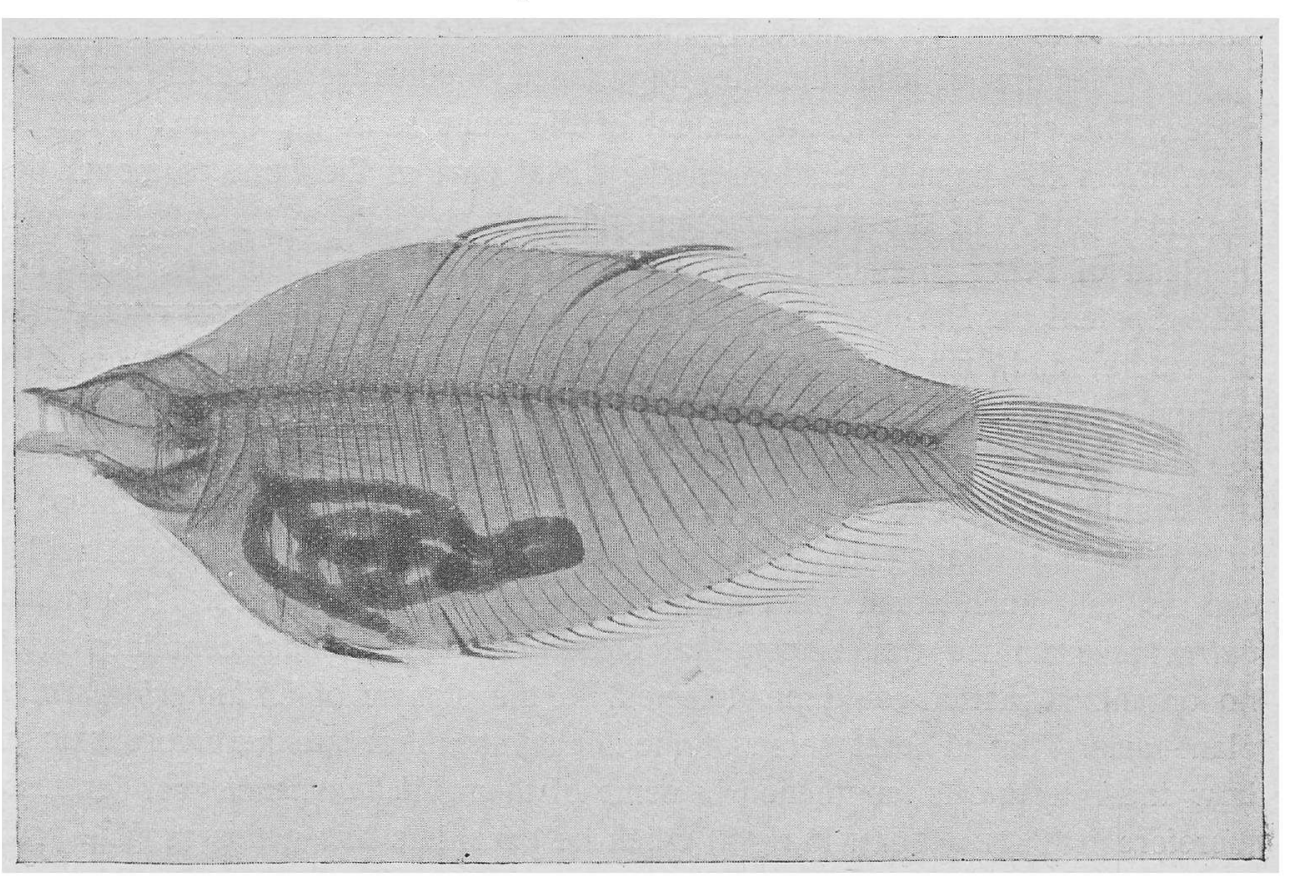

Fig. 5. Röntgen-foto of Melanotaenia dumasi M. Web., showing the skeleton and the intestinal tract in situ.

two coils before the anus is absent.

As in all Atherinidae, pyloric appendages are absent. The liver is comparatively small. A large gall-bladder is present.

The air-bladder is large, thin-walled and firmly attached to the ribs. It is prolonged into the postanal part of the body-cavity and ends below the last rib-bearing vertebra, as has already been mentioned above. In Rhombatractus kochi, where the gut does not penetrate into lastnamed cavity, the 
air-bladder fills it here completely from the vertebral column to the pterygophores of the anal fin. 3. Genital and Urinary organs. In the specimen of Rhombatractus kochi examined, the testes form one single organ, opening behind the anus. The same is the case in Chilatherina sentaniensis. In another, female specimen of this species, I found one ovarium developed, with large, but not yet ripe eggs.

The kidneys have the usual position. A large muscular bladder is present.

In what way now do the Melanotaeniinae differ from other Atherinidae besides in external characters? In their osteology they show typical atherinoid characters, as has already been stated by TAte REgan. Still there are special features, by which a skeleton of a Melanotaeniid fish can be recognized. Most of these can be derived from the compressed, elevated form of the body, such as the lengthening of the pterygophores, the long ribs, the perpendicular position of the pelvics. But besides, there are others.

It is clear, that every change in the form of the body of a fish changes the position of its centre of gravity and that a shifting of the position of the fins is necessary to regain the lost stability. We may therefore consider the forward prolongation of second dorsal and anal as a consequence of the body being compressed and elevated.

From the elongation of the anal results, that the abdominal cavity is lessened and that the anus is pushed forward. I wish to remember here, that in many Atherinidae the anus is situated far in front of the anal fin and the question might be put, if this forward position of the anus is the remnant of a condition, in which the anal was longer. If so, the Melanotaeniid condition is a primitive one and if, as has been suggested, the Percesoces are of percoid origin, the low number of vertebrae and the pungent spines of the Melanotaeniinae are primitive characters too. However, the anatomy of the Atherinidae is not yet sufficiently known to settle this question.

A feature of considerable importance I consider to be the form of the praemaxilla, described above. The chief point of attachment of the bone is at the place, where it is bent, so that it is fixed here. From this results, that when the distal part of the bone is moved forwards and backwards, the proximal part with the numerous and rather large teeth on its outside moves downwards and upwards. In stead of being prehensile, the jaws make scraping movements. I expierenced this when bathing in Lake Sentani, in Northern New Guinea. Chilatherina sentaniensis occured there in large numbers along the shore, and, when standing bare-legged in the clear water, I could feel and see how the fishes scraped at the skin of my legs.

This makes me suppose, that one of the ways, in which the Melanotaeniinae get their food, is by scraping off stones and other objects in the water, although I must add, that they are also able to seize food floating in the water, as they could easily be caught with the rod baited with rice. I can not tell much about what kind of food they generally take. The stomac of the specimen of Rhombatractus examined was empty, that of Melanotaenia dumasi contained mud, as stated above, in which no organized matter could be detected. In the stomac of Chilatherina sentaniensis I found among mud, plant-rests. That at least some of the Melanotaeniinae are herbivorous is probable, when we consider how the intestine is lengthened in some of them. Melanotaenia goes farthest in this respect and I doubt therefore if TATE REGAN is right, when he considers this genus as "the prototype of the whole group".

One is tempted to ask, considering the controversy about the Melanotaeniinae being "freshwaterfishes" or not, if the features discussed above might be called adaptations to the life in freshwater. I do not think a positive answer is possible. An elevated, compressed form certainly is often met with in freshwater-fishes, which are no ground feeders (f. i. many. Cyprinoids and Characinoids). The advantages of such a body-form are clear. The resistance of the water, when swimming against strong currents, is diminished to the least, whereas the height of the body allows nevertheless the development of strong muscles in the tail, which chiefly achieves locomotion. This form of body however is not restricted to freshwater-fishes. It occurs just as commonly among sea-fishes, specially among "coral-fishes". 
I consider the structure of the mouth as the most essential feature of the Melanotaeniinae. There are other Atherinidae, which are compressed and have relatively long vertical fins, as Telmatherina from the interior of Celebes and Bedotia from the freshwater of Madagascar, but they have the ordinary protractile mouth of the other Atherinidae. In the Atherinopsinae from shores and streams of the New World, the gape is also strongly curved, but according to the descriptions the resemblance is only superficial.

As said, I am inclined tot see in the mouth-structure of the Melanotaeniinae an adaptation to a habit of "grazing off" objects in the water and this with the form of the body makes these fishes especially suited to the life in clear brooks with a hard rocky bottom. In such localities I found these fishes abundantly, but as my experience does not go farther than some parts of New Guinea and Waigeu, it would be interesting to know the mode of life in other places, specially in Australia.

\section{LITERATURE.}

1. L. F. DE BEAUfORT, Weitere Bestätigung einer zoogeographischen Prophezeiung. Zool. Anzeiger Bd. XXXVI. 1910, p. 249.

2. D. STARR JORDAN \& C. L. HUBBS, A Monographic Review of the Family Atherinidae or Silversides. Leland Stanford University Publications. University Series. 1919.

3. MAX WEBER, Süsswasserfische von Neuguinea. Ein Beitrag zur Frage nach dem früheren Zusammenhang von Neuguinea und Australien. Nova Guinea V. Livr. 2. 1907, p. 201.

4. MAX WeBer, Eine zoogeographische Prophezeiung. Zool. Anzeiger Bd. XXXII. 1907, p. 401.

5. E. C. Starks, The Osteological Characters of the Fishes of the suborder Percesoces. Proc. U. S. Nat. Museum. XXII. 1899 , p. 1.

6. C. TATE REGAN, Report on the freshwater fishes collected by the British Ornithologists' Union Expedition and the Wollaston Expedition in Dutch New Guinea. London Trans. Zool. Soc. XX. 1914, p. 275. 